\title{
Nomenclatural corrections in Mesoamerican Plantaginaceae and a new species of Tetranema from Honduras
}

\section{Christenhusz, Maarten}

2010-12-24

Christenhusz , M 2010 , ' Nomenclatural corrections in Mesoamerican Plantaginaceae and a new species of Tetranema from Honduras ' , Phytotaxa, vol. 14 , pp. 56-60 .

http://hdl.handle.net/10138/28043

submittedVersion

Downloaded from Helda, University of Helsinki institutional repository.

This is an electronic reprint of the original article.

This reprint may differ from the original in pagination and typographic detail.

Please cite the original version. 


\title{
Nomenclatural corrections in Mesoamerican Plantaginaceae and a new species of Tetranema from Honduras
}

\author{
MAARTEN J. M. CHRISTENHUSZ \\ Botanical Garden and Herbarium, Finnish Museum of Natural History, University of Helsinki, 00014 Helsinki, Finland. \\ E-mail: maarten.christenhusz@helsinki.fi
}

\begin{abstract}
Study of the Plantaginaceae for the Flora Mesoamericana project has resulted in five lectotypifications, a new combination in Rhodochiton, and the discovery of a new species of Tetranema from Honduras. This species, Tetranema michaelfayanum, is described here, a key to the species of Tetranema is provided, and the T. roseum complex is discussed.
\end{abstract}

\section{Introduction}

The family Plantaginaceae sensu APG III (2009) and as discussed by Fay et al. (2010) includes a number of non-parasitic Scrophulariaceae s.l. In its modern sense it is difficult to define. Within the Flora Mesoamericana area (Chiapas, Tabasco, Yucatan peninsula, Belize, Guatemala, Honduras, El Salvador, Nicaragua, Costa Rica and Panama) Plantaginaceae includes 25 genera; apart from the type genus Plantago L. (with 3 native and 2 introduced species), the genera: Achetaria Cham. \& Schltdl. (1 species), Angelonia Humb. \& Bonpl. (3 native species), Antirrhinum L. (1 introduced species), Bacopa Aublet (9 species), Benjaminia Mart. ex Benj. (1 native species), Callitriche L. (2 confirmed native species), Conobea Aublet (1 native species), Cymbalaria Hill. (1 introduced species), Darcya B.L.Turner \& C.Cowan (2 native species), Digitalis L. (1 introduced species), Gratiola L. (1 native species), Lophospermum D.Don ex R.Taylor (2 native species), Maurandya Ortega (2 native species), Mecardonia Ruiz \& Pavón (1 native species), Penstemon Schmidel (2 native species), Rhodochiton Zucc. ex Otto \& Dietr. (2 native species), Russelia Jacq. (ca. 12 native species), Schistophragma Benth. ex Endl. (1 native species), Scoparia L. (2 native species), Sibthorpia L. (1 native species), Stemodia L. (5 native species), Tetranema Benth. (4 + 1 new species), Uroskinnera Lindl. (2 native species), and Veronica L. (2 native +5 introduced species) are revised for the flora.

During my studies of Plantaginaceae for the Flora Mesoamericana, I found one new species of Tetranema. Additionally one new combination in Rhodochiton is proposed and five species are typified.

\section{A new species of Tetranema}

\section{Introduction}

Tetranema Benth. in Lindley (1843) is a small genus with five species occurring only in Mexico and Central America. It occurs from Puebla and Veracruz in Mexico south to Costa Rica. The genus was first thought to be part of Gesneriaceae when Episcia rosea Martens \& Galeotti (1842: 39) was published. Tetranema mexicanum Benth. in Lindley (1843) was first mentioned as a member of Scrophulariaceae. No 
type specimen was mentioned originally, but Bentham (1846) later cited Galeotti 1905 (among other specimens) on which Episcia rosea was based. That name having priority, the two names were united as $T$. roseum (M.Martens \& Galeotti) Standley \& Steyermark (1947: 235).

Allophyton megaphyllum Brandegee (1914: 62) was then proposed, but Pennell (1925) decided that Tetranema and Allophyton were congeneric and accepted the second name for the genus because the name Tetranema Sweet was already in use for a genus of Fabaceae. Tetranema of Bentham was, however, conserved against Tetranema of Sweet by the IBCN Amsterdam in 1935, after which the combination T. megaphyllum (Brandegee) Williams (1972: 131) was made. In the same publication, a new species, T. bicolor Williams (1972: 127), was proposed, which was later found to belong to the genus Napeanthus (Gesneriaceae) (Stevens et al. 2001), continuing the confusion of the placement of Tetranema.

Méndez-Larios \& Villaseñor (1995) published a revision of Tetranema, but this included no specimens from Costa Rica. In the same year, Grayum \& Hammel (1995) published a revision of Tetranema in Costa Rica, and described two new species: T. floribundum Hammel \& Grayum (in Grayum \& Hammel 1995: 276) and T. gamboanum Grayum \& Hammel (1995: 270).

\section{Key to the species of Tetranema}

1. Stamens included; corolla funnel-shaped, white with violet steaks to purple or blue

1. Stamens exserted from the throat of the corolla (but not exceeding the upper corolla lobe); corolla tubular, red or scarlet.

2. Leaves condensed in a pseudo-rosette, obovate, the internodes short $(\leq 1 \mathrm{~cm})$ T. roseum

2. Leaves spaced along the stem, oblanceolate, the internodes longer $(\geq 3 \mathrm{~cm})$. T. michaelfayanum

3. Plant $25-50 \mathrm{~cm}$; corolla lobes $2-4 \mathrm{~mm},<1 / 5$ the total corolla length; floral bracts ca. $6-10 \mathrm{~mm}$..........T. megaphyllum

3. Plants (35-)80-200 cm; corolla lobes $11-13 \mathrm{~mm}$ long, $>1 / 5$ the total corolla length; floral bracts $0.5-5 \mathrm{~mm} . . . \ldots \ldots \ldots . . .4$

4. Corolla $2.6-3.5 \mathrm{~cm}$, pubescent within in a band of flat, yellow hairs along the entire ventral surface and onto the lower lobe; inflorescence many-flowered (14-30 flowers), the peduncle purple; leaf apex rounded to short-acuminate ....... T. floribundum

4. Corolla ca. 4.9-5.5 cm, glabrous throughout or (rarely) pubescent on lower lobe and at mouth; inflorescence few-flowered (2-12 flowers), the peduncle green; leaf apex long-acuminate T. gamboanum

\section{Tetranema michaelfayanum Christenh., sp. nov.}

Species cum Tetranemate roseo optime congruens sed differt foliis oblanceolatis et internodis multo longioribus.

Type:-HONDURAS. Comayagua: ridge of Cerro El Maneadero, ca. $11 \mathrm{~km}$ of Lago Yojoa, Parque Nacional Azul Meámbar, 1740 m, 1448'00”N, 8752'30'”W, primary forest, 11 March 1993, Evans 1354 (holotype $\mathrm{BM}$ !, isotype $\mathrm{MO} !)$.

Herbs to at least $50 \mathrm{~cm}$. Stems elongate, pubescent, the internodes $3 \mathrm{~cm}$ or longer. Leaves subsessile to short-petiolate, petioles (when present) to ca. $1 \mathrm{~cm}$. Leaves $11.5-19 \times 3-5.5 \mathrm{~cm}$, oblanceolate, the base attenuate, the apex acute to acuminate, the margins distantly crenate, ciliate with bicellular trichomes, glabrous above, villous on the veins beneath. Inflorescences densely clustered, cymose, pseudo-umbellate; peduncles ca. 12-16 cm (usually longer than the leaves), green, quadrangular with the angles narrowly winged; bracts $1.5-2 \mathrm{~mm}$, linear. Flowers (4-)6-12, with pedicels ca. 5-10 mm. Calyx 3-5 mm, the lobes imbricate, lanceolate, the apex acuminate. Corolla ca. $1.5 \mathrm{~cm}$, infundibular, white with violet tube, bilabiate, the upper lip ca. $4 \mathrm{~mm}$, bilobed, the lobes partly fused, rounded, the lower lip ca. 5-6 mm, trilobed, the middle lobe elliptic-ovate, the lateral lobes ovate. Stamens included, the shorter pair ca. $4 \mathrm{~mm}$, the longer pair ca. 5 $\mathrm{mm}$, the staminode ca. $3 \mathrm{~mm}$. Style included. Capsule ca. $5 \mathrm{~mm}$, ovoid. Seeds subquadrangular, ca. $4 \mathrm{~mm}$. Flowering in March. 
Etymology:-This species is named in honour of Dr. Michael F. Fay, head of Genetics at the Jodrell Laboratory, Royal Botanic Gardens, Kew. His extensive work on plant conservation and great achievement as editor in chief of the Botanical Journal of the Linnean Society, and editorial work for other journals including Phytotaxa are hereby acknowledged.

\section{Discussion}

In Tetranema, two different types of flowers occur: white to violet corollas with incised upper lobes and included stamens, and red corollas with fully fused upper lobes and exserted stamens. The first is most likely bee-pollinated and is found usually on plants with short stem internodes, making the leaves appear rosulate (e.g. T. roseum). The second is probably pollinated by hummingbirds and is found on bushy plants with long stem internodes (T. megaphyllum, T. gamboanum, T. floribundum). The new species, T. michaelfayanum, combines these characters in having bee-pollinated violet flowers on large plants with long stem internodes.

Because the flower-type of $T$. michaelfayanum resembles that of the $T$. roseum complex, I feel it is necessary to discuss this species here. Traditionally, three taxa were recognised in this complex: Tetranema cymosum Williams (1972: 129), T. evolutum Smith (1889: 29), and T. roseum. Tetranema evolutum was distinguished by its multicellular cilia along the leaf margins and lax cymes, whereas T. roseum has bicellular cilia and pseudo-umbellate inflorescences. These differences are, however, not consistent in combination, and thus I opted for merging these species. Méndez-Larios \& Villaseñor (1995) distinguished T. evolutum, T. cymosum and $T$. roseum based on corolla colour, respectively red, white and violet, but all the specimens I studied labeled T. evolutum, including the type, list the colour as violet-purple or white with a violet or purple throat. The type specimen of T. cymosum describes the corolla as 'white, dull purple at base of tube with dull purplish spots on upper side', which is not very different from other Guatemalan specimens. It does have a more lax inflorescence and shorter stamens, but these traits may reflect individual phenotypic variation.

\section{New combination}

Rhodochiton Zucc. ex Otto \& Dietrich and Lophospermum D.Don share many characters, and have been suggested to be congeneric. Elisens (1985) makes strong arguments for this and merged the two genera, but they differ in characters of the calyx and peduncle. Phylogenetic analysis (Ghebrehiwet et al. 2000) shows the two genera as sister taxa, and because the name Rhodochiton atrosanguineum (Zucc.) Rothmahler (1943: 25) is commonly in use in the horticultural trade, I opted in the Flora Mesoamericana to keep them separate. But to do this, one Mesoamerican Lophospermum species needs to be transferred to Rhodochiton, as proposed here:

Rhodochiton nubicola (Elisens) Christenh., comb. nov.

Basionym: Lophospermum nubicola Elisens (1985: 83). Type: MEXICO. Chiapas: Matuda 2359 (holotype MEXU, isotypes F!, LL, MICH)

\section{Typifications}

Angelonia angustifolia Bentham (1846: 254). Lectotype (designated here): MEXICO. anno 1840, Galeotti 1013 (K!, duplicate MO!).

Note:-The protologue lists six syntypes: 'In campis prope Xalapa et Vera-Cruz, in Mexico (Alaman!, Galeotti! n. 1013, Linden! n. 206)', 'v. in herb. DC et Hooker'.

All six original specimens (three in G-DC and three in $\mathrm{K}$ ) are in existence; the specimen selected here is annotated by Bentham, is well-preserved and shows all characters necessary for identification of the species. 
Bacopa aquatica Aublet (1775: 129, t. 49). Lectotype (designated here): FRENCH GUIANA. Aublet s.n., BM-000838070!).

Note:-Two original specimens are preserved (in BM and LINN-SM-279.1 in the J.E. Smith Herbarium). The specimens are equal; the BM specimen is selected here as the lectotype.

Bacopa monnierioides (Cham.) Robinson (1909: 614). Ranaria monnierioides Chamisso (1833: 31), Linnaea 8: 31 (1833). Lectotype (designated here): BRAZIL. Sellow s.n. (K-000533423!)

Note:-No precise location of the Sellow specimen was cited in the original protologue. There is a good representative original specimen at $\mathrm{K}$, which will serve well as the lectotype for this name.

Schistophragma mexicanum Benth. ex Endl. in Dietrich (1843: 513). Lectotype (designated here): MEXICO. anno 1837, Alaman s.n. ex Herbarium Benthamianum, (K-000529076!).

Note:-The name was based on a manuscript by Endlicher and no specimens were cited. There is original material from the Bentham Herbarium at K, which is hereby selected as the lectotype.

Veronica plebeia Brown (1810: 435). Lectotype (designated here): AUSTRALIA. New South Wales: Port Jackson, Brown s.n. (BM!).

Note:-Briggs \& Ehrendorfer (2006) wrote 'Holotype: [New South Wales] in humidis prope Sydney, $R$. Brown, May 1802 (BM!)', but this is incorrect because there is no holotype selected in the original description. The protologue is accompanied by '(J)', which refers to specimens collected at Port Jackson, as observed or collected by Brown himself (see Brown 1810: vi-viii). Therefore the specimen chosen here is a more appropriate lectotype for this name.

\section{References}

APG III (2009) An update of the Angiosperm Phylogeny Group classification for the orders and families of flowering plants: APG III. Botanical Journal of the Linnean Society 161: 105-121.

Aublet, F. (1775) Histoire des plantes de la Guiane Françoise. Pierre-François Didot jeune, London \& Paris.

Bentham, G. (1846) Scrophulariaceae, in: Candolle, A.P. de (ed.) Prodromus systematis naturalis regni vegetabilis $10:$ 186-586. Victoris Masson, Paris.

Brandegee, T.S. (1914) Plantae mexicanae purpusianae, VI. University of California Publications in Botany 6: 51-77.

Briggs, B.G. \& Ehrendorfer, F. (2006) New Australian species and typifications in Veronica s. lat. (Plantaginaceae). Telopea 11: 276-292.

Brown, R. (1810) Prodromus Florae Novae Hollandiae et Insulae Van-Diemen. Richard Taylor \& Soc., London.

Chamisso, A. de (1833) Spicilegium plantarum e familiis jam prius recensitis, praesertim Brasiliensium serius a Sellowio. Scrofularineae. Linnaea 8: 17-112.

Dietrich, D. (1843) Synopsis plantarum seu Enumeratio systematica, vol. 3. B.F. Voigt, Weimar.

Elisens, W.J. (1985) Monograph of the Maurandyinae (Scrophulariaceae-Antirrhinae). Systematic Botany Monographs 5: $1-97$.

Fay, M.F., Bennett, J.R., Dixon, K.W. \& Christenhusz, M.J.M. (2010) Parasites, their relationships and the disintegration of Scrophulariaceae sensu lato. Curtis's Botanical Magazine 26: 286-313.

Ghebrehiwet, M., Bremer, B. \& Thulin, M. (2000) Phylogeny of the tribe Antirrhineae (Scrophulariaceae) based on morphological and $n d h F$ sequence data. Plant Systematics and Evolution 220: 223-239.

Grayum, M.H. \& Hammel, B.E. (1995) The genus Tetranema (Scrophulariaceae) in Costa Rica, with two new species. Phytologia 79: 269-280 (1995).

Lindley, J. (1843) Tetranema mexicanum. Edwards's Botanical Register: or, ornamental flower-garden and shrubbery 28(6): plate 52.

Martens, M. \& Galeotti, H. (1842) Enumeratio synoptica plantarum phanerogamicarum ab Henrico Galeotti in regionibus Mexicanis collectarum, Gesneriaceae. Bulletins de l'Academie Royale des Sciences et des Belles-Lettres de Bruxelles 9(2): 32-39.

Méndez-Larios, I. \& Villaseñor, J.L. (1995) Revisión taxonómica del género Tetranema (Scrophulariaceae). Acta Botanica Mexicana 32: 53-68.

Pennell, F.W. (1925) The genus Allophyton of southern Mexico and Guatemala. Proceedings of the Academy of Natural 
Sciences of Philadelphia 77: 269-272.

Robinson, B.L. (1909) Diagnoses and transfers of tropical American phanerogams. Proceedings of the American Academy of Arts and Sciences 44: 613-626.

Rothmahler, W. (1943) Zur Gliederung der Antirrhineae. Feddes Repertorium Specierum Novarum Regni Vegetabilis 52: 16-39.

Smith, J.D. (1889) Undescribed plants from Guatemala VI. Botanical Gazette 14: 25-30.

Standley, P.C. \& Steyermark, J.A. (1947: 235) Studies of Central American plants - VII. Publications of the Field Museum of Natural History, Botanical Series 23: 193-265.

Stevens, W.D., Ulloa Ulloa, Pool, A. \& Montiel, O.M. (2001) Flora de Nicaragua. Monographs in Systematic Botany from the Missouri Botanical Garden 85: i-xlii, 1-2666.

Williams, L.O. (1972) Tropical American plants, XII. Fieldiana, Botany 34: 101-132. 